\title{
Romatoid Artritli Hastada Akupunktur Uygulamasının Ölümcül Komplikasyonu: Nekrotizan Fasiit
}

\author{
A Fatal Complication of Acupuncture in a Patient with Romatoid \\ Arthritis: Necrotizing Fasciitis
}

Alkin Çolak, Dilek Memiş, Hüseyin Kandulu*, Hüsamettin Top*, Murat Kargı

Trakya Üniversitesi Tıp Fakültesi, Anesteziyoloji ve Reanimasyon Anabilim Dalı, Edirne, Türkiye

*Trakya Üniversitesi Tıp Fakültesi, Plastik ve Rekonstrüktif Cerrahi Anabilim Dalı, Edirne, Türkiye

\section{ÖZET}

Akupunktur, bazı durumlarda tıbbi ya da cerrahi tedavilere alternatif olarak kullanılmaktadır. Akupunktur güvenli bir yöntem olarak kabul edilmesine rağmen literatürde fatal ya da çok ciddi komplikasyonlar bildirilmiştir. Romatoid artrit tedavisi için akupunktur tedavisi uygulanan ve buna bağlı olarak oluşan mortal nekrotizan fasiit olgusunu sunmayı amaçladık. (Türk Yoğun Bakım Derneği Dergisi 2011; 9: 23-5)

Anahtar Kelimeler: Akupunktur, akupunktur komplikasyonları, nekrotizan fasiit, yara infeksiyonu

\section{SUMMARY}

Acupuncture is used for some conditions as an alternative to medication or surgical intervention. Acupuncture is a relatively safe procedure but fatal and near fatal complications have been reported in the international literature. We report a case where fatal necrotizing fasciitis developed in a patient who had acupuncture treatment for romatoid arthritis of the knee. (Journal of the Turkish Society of Intensive Care 2011; 9: 23-5)

Key words: Acupuncture, acupuncture complications, necrotizing fasciitis, wound infection

Yazışma Adresi/Address for Correspondence: Dr. Alkin Çolak, Trakya Üniversitesi Tip Fakültesi, Anesteziyoloji ve Reanimasyon Anabilim Dalı, 22030, Edirne, Türkiye Tel.: +90 28423576 41/2156 Faks: +90 2842358096 E-posta: alkincol@yahoo.com Geliş Tarihi/Received: 05.01.2011 Kabul Tarihi/Accepted: 12.04.2011 


\section{Giriş}

Akupunktur geleneksel Çin tıbbının önemli bir bileşenidir. Bu prosedür Batı ülkelerinde ağrı tedavisinde, sigara içimi ve şişmanlık gibi problemlerin tedavisinde kullanılmaktadır. Birçok akupunkturist tarafından noninvaziv bir prosedür olarak kabul edilse de komplikasyonsuz değildir. Akupunktur iğneleri yüzünden fiziksel yaralanmalar, bölgesel veya sistemik enfeksiyonlar oluşabilmektedir (1-3).

Nekrotizan fasiit, fasya ve deri altı doku içeren bir hayatı tehdit eden bir enfeksiyondur (4). Bu yazıda romatoid artrit tedavisi için akupunktur tedavisi uygulanan ve buna bağlı olarak oluşan mortal nekrotizan fasiit olgusunu sunmayı amaçladık.

\section{Olgu Sunumu}

Otuz dokuz yaşında bayan, sağ alt ekstremitede şişlik, ağrı, kızarıklık şikayeti ile acil servise başvurdu. Acil servise başvurmasından 3 gün önce sağ dizindeki romatoid artrite bağlı ağrı için dış merkezde akupunktur tedavisi uygulandığını, iğne batırılan yerlerde ağrının arttığını ve akıntı olması nedeniyle acil servise başvurduğu öğrenildi. Akupunktur iğnelerinin steril olup olmadığını bilmediğini ve iğne batırılan yerlerin sadece ıslak mendil ile silinip başka bir dezenfektan uygulanmadığını bildirdi. Yaklaşık 10 yıldır romatoid artrit hastası olduğu son 3 yıldır da analjezik ilaçlar dışında herhangi bir ilaç kullanmadığı öğrenildi.

Fizik muayenesinde subfebril ateş $\left(37,5^{\circ} \mathrm{C}\right)$, kalp atım hızı: 96 atım/dk, arteriyel kan basıncı 104/59 mmHg olarak saptandı. Sağ ayak bileğinde soğukluk ve büller, sağ diz üzerinden başlayarak kasığa kadar uzanan şişlik, sertlik ve büller mevcuttu. Sağ diz ve hemen diz altında 4 iğne giriş yeri olduğu görüldü. Palpasyonla krepitasyon saptanmadı ve distal nabızlar palpe ediliyordu (Şekil 1, 2).

Kan sayımı ve biyokimyasal testlerde lökosit: 22,100 mm33, Hg: 8,7 g/dl, Htc: \%26,3, albümin: 1,4 g/dl, total protein: 5,3 g/dl idi. Yapılan değerlendirmeler sonucu

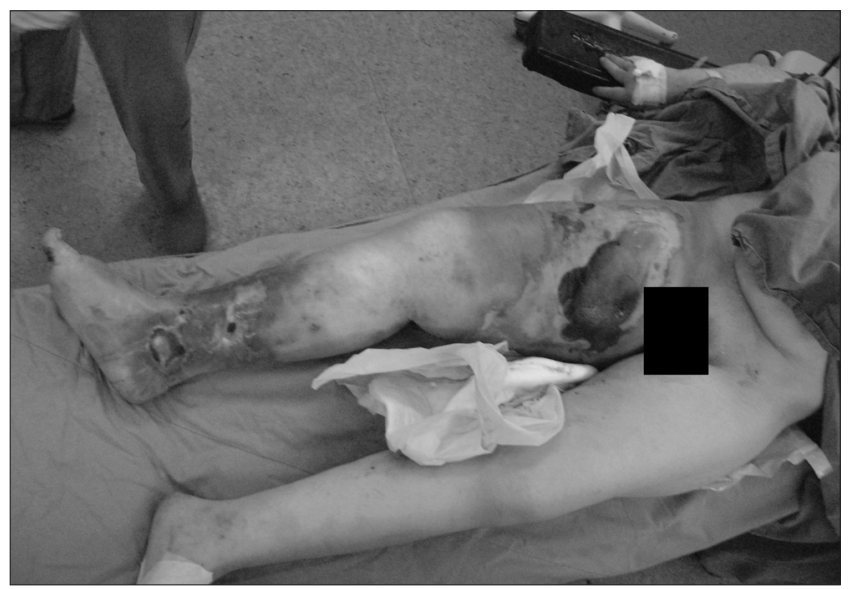

Resim 1. Bacağın medial görünümü nekrotizan fasiit düşünülerek genel anestezi altında uyluk ön yüze, bacak medialine ve ayak sırtına 3 farklı kesiden fasyotomi ve enfekte dokuların debridmanı yapıldı. Yara yerlerinden alınan kültürde A grubu beta hemolitik streptokok üremesi üzerine enfeksiyon hastalıkları uzmanının önerisi ile hastaya imipenem+silastatin 500 mg x 4 intravenöz başlandı. Plastik cerrahi servisine alınan hastanın operasyondan sonraki ikinci günde dakika solunum sayısı artan, periferik siyanozu olan hastanın arteriyel tansiyonu 93/52 mmHg, kalp tepe atımı 118/dk, vücut sıcaklığı: $38.3^{\circ} \mathrm{C}$ olarak saptandı. Maske ile $6 \mathrm{lt} / \mathrm{dk}$ oksijen alıyorken arter kan gazı analizinde $\mathrm{pH}: 7,41, \mathrm{PO}_{2}: 53,4 \mathrm{mmHg}$, $\mathrm{PCO}_{2}$ : $35.1 \mathrm{mmHg}, \mathrm{HCO}_{3}: 21 \mathrm{mmol} / \mathrm{L}, \mathrm{BE}:-2,2$ saptanan hasta yoğun bakım ünitesine alındı.

Analjezi ve sedasyon uygulanan hasta solunum cihazına bağlandı. Arter kan gazı analizinde $\mathrm{FiO}_{2}$ : \%70, $\mathrm{pH}:$ 7,27, $\mathrm{PO}_{2}:$ 40,2 mmHg, $\mathrm{PCO}_{2}: 45,4 \mathrm{mmHg}, \mathrm{HCO}_{3}$ : 20,3 mmol/L, BE: -5,3, arteriyel kan basıncı 95/55 mmHg, kalp atım hızı 143 atım/dk olarak bulundu. Santral venöz kateter takılan hastanın santral venöz basıncı $12 \mathrm{cmH}_{2} \mathrm{O}$ olarak ölçüldü. Hastaya dopamin ve dobutamin infüzyonu başlandı. PA akciğer grafisinde alt zonlarda infiltrasyon saptandı. Kan kültüründe Acinetobacter baumannii üremesi üzerine klindamisin $3 \times 600 \mathrm{mg}$, kristalize penisilin 6x4 milyon Ü ve trimetoprim-sülfometaksazol 3×160 mg başlandı. Fibrinojen: 730 mg/dl (Ref: 200-400), D-dimer: 20 üzerinde mg/ml (Ref: 0-0,05) olan hastaya yaygın damar içi pıhtılaşma sendromu tanısı ile taze donmuş plazma replasmanı yapıldı. Albümin değerinin 1,9 g/dl (Ref: 3,5-4,8) olması nedeniyle \%20 human albüminden $100 \mathrm{ml} \times 2$ başlandı. Idrar çıkışının az olması, üre ve kreatinin değerlerinin yükselmesi üzerine devamlı venö-venöz hemofiltrasyon uygulanmaya başlandı. Olgumuz yoğun bakım ünitesine gelişinin 70. saatinde çoklu organ yetmezliği nedeniyle kaybedildi.

\section{Tartışma}

Akupunktur, tamamlayıcı ve alternatif tıp olarak yaygın uygulanır hale gelmiştir. Son 10 yılda kullanımı artmış olup, artmaya devam etmektedir. Çin'de 5000 yıllık geç-

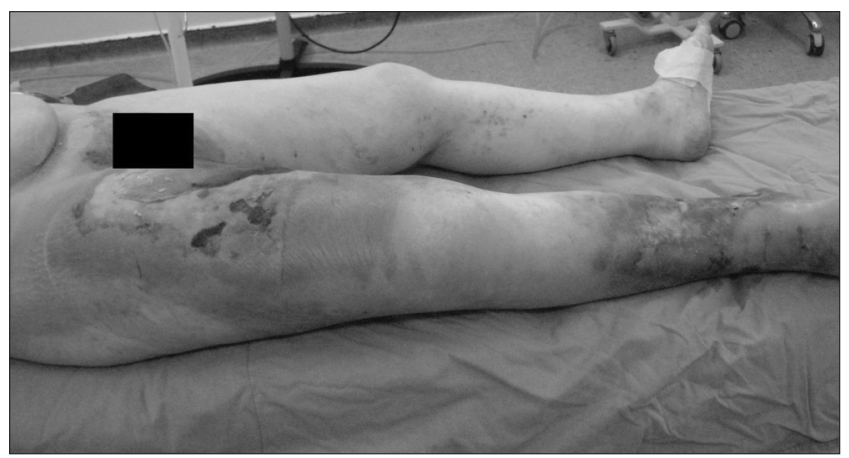

Resim 2. Bacağın lateral görünümü 
mişi ile tıpta alternatif bir form olarak kullanılan akupunktur tedavisinin pek çok hasta tarafından güvenli ve etkili olduğuna inanılmaktadır (5). Akupunktur uygulamasına bağlı komplikasyon oranı $1 / 10.000$ 'den az olarak bildirilmiştir $(5,6)$.

Zhang ve ark. (7) tarafindan yapılan bir derlemede romatoid artrit tedavisinde kullanılan geleneksel ilaçların yanında adjuvan olarak herbal tedavi, akupunktur ve masaj uygulamalarının romatoid artrit tedavisinde yararlı olabilecek yeni yaklaşımlar olduğunu bildirmiş̧lerdir.

Akupunktur tedavisi güvenli bir girişim olarak bilinmesine rağmen literatürde fatal komplikasyonlarının olduğu bildirilmiştir (1). Travmatik pnömotoraks (8), kardiyak tamponad (9) ve septisemi (10) fatal komplikasyonlardan bazilarıdır.

Akupunktura bağlı enfeksiyöz komplikasyonların tanımlanması zordur, ancak viral ve bakteriyel patojenlerin tanımlandığı yayınlar mevcuttur (5). Akupunktura bağlı oluşan, girişim yerindeki veya sistemik enfeksiyonların uygulama sırasında steriliteye dikkat edilmemesi ile ilişkili olduğu bildirilmektedir. Örneğin, girişimden önce iğnenin ısıtılması ile iğnenin sterilizasyonu sağlanabilir, ancak girişim yapılan bölgenin uygun temizliği yapılmadığında sterilite yetersizdir (4).

Akupunkturda kullanılan iğnelerin ve uygulanacak bölgenin sterilitesinin sağlanmadığı durumlarda lokal yara yeri enfeksiyonundan sepsise kadar giden değişik sonuçlar olasıdır. Akupunktura bağlı oluşan bakteriyel enfeksiyonlar sıkıkla iğne giriş yerinde olan lokal selülitlerdir (11). Ancak endokardit, spinal epidural apse, nekrotizan fasiit gibi ciddi enfeksiyonlar ve sepsis olguları da bildirilmiştir (4). Bir olgu serisinde 16 hastanın 9'unda sorumlu patojen Staphylococcus aureus olarak saptanmıştır. Literatürde stafilokok sepsisine bağlı iki olgu sunumu mevcuttur. Bunlardan başka sorumlu organizmalar Pseudomonas aeruginosa, streptokoksik türler, Propionibacterium acnes, Mycobacterium chelonae olarak bildirilmiștir (1). Bu enfeksiyonların çoğu epidermal bariyeri bozuk immün sistemi baskılanmış diyabetik hastalarda görülmüştür.

Nekrotizan fasiit diabetes mellituslu hastalarda daha sık görülen ve hayatı tehdit eden bir durumdur. Fizyolojik bulgular ile tanı koymak zor olabilir. Ayrıca krepitasyon da her zaman mevcut değildir (12). Wall ve ark. (13) lökosit sayısının $14 \times 109 / L$ 'den fazla olması, serum sodyum düzeyinin $135 \mathrm{mmol} / \mathrm{L}$ 'den az olması ve kan üre azotunun 15 $\mathrm{mg} / \mathrm{dL}$ 'den fazla olmasının nekritizan fasiit ile hafif seyirli yumuşak doku enfeksiyonlarının ayııııı tanısında yararlı olduğunu bildirmişlerdir. Lokal anestezi ile alınan doku biyopsisinin frozen ile incelenmesinin de tanıya yardımcı olacağı bildirilmiş̧ir (14). Bizim hastamızın ilk değerlendirmesinde fizyolojik bulgular ile hematolojik ve biyokimyasal testler sonucunda ön tanı olarak nekrotizan fasiit düşünüldü. Yara yerinden alınan kültürde A grubu beta hemolitik streptekok, kan kültüründe ise Acinetobacter baumannii üredi. Tüm tedavilere rağmen hastamız kaybedildi.

Sonuç olarak; akupunktur uygulanacak bölgenin normal anatomisi ve buralarda olabilecek temel anatomik varyasyonlar hakkında bilgi sahibi olunmalı, ayrıca sterilite konusunda daha dikkatli davranılmalıdır. Akupunktur tedavisi noninvaziv bir girişim olarak görülse de, steriliteye dikkat edilmediğinde hayatı tehdit eden bir tehlike olabileceği unutulmamalıdır.

\section{Kaynaklar}

1. Ernst $E$, White A. Life-threatening adverse reactions after acupuncture? A systematic review. Pain 1997;71:123-6.

2. Peuker $E$, Grönemeyer D. Rare but serious complications of acupuncture: traumatic lesions. Acupunct Med 2001;19:103-8.

3. Peuker ET, White A, Ernst E, Pera F, Filler TJ. Traumatic complications of acupuncture. Therapists need to know human anatomy. Arch Fam Med 1999;8:553-8.

4. Saw A, Kwan MK, Sengupta S. Necrotising fasciitis: a life-threatening complication of acupuncture in a patient with diabetes mellitus. Singapore Med J 2004;45:180-2.

5. Seeley EJ, Chambers HF. Diabetic ketoacidosis precipitated by Staphylococcus aureus abscess and bacteremia due to acupuncture: case report and review of the literature. Clin Infect Dis 2006;43:6-8

6. White A. A cumulative review of the range and incidence of significant adverse events associated with acupuncture. Acupunct Med 2004;22:122-33

7. Zhang P, Li J, Han Y, Yu XW, Qin L. Traditional Chinese medicine in the treatment of rheumatoid arthritis: a general review. Rheumatol Int 2010;30:713-8.

8. Iwadate K, Ito H, Katsumura S, Matsuyama N, Sato K, Yonemura I, etal. An autopsy case of bilateral tension pneumothorax after acupuncture. Leg Med (Tokyo) 2003;5:170-4.

9. Hasegawa J, Noguchi N, Yamasaki J, Kotake H, Mashiba H, Sasaki S, et al. Delayed cardiac tamponade and hemothorax induced by an acupuncture needle. Cardiology 1991;78:58-63.

10. Pierik MG. Fatal Staphylococcal septicemia following acupuncture: report of two cases. Occurrence of Staphylococcal septicemia following acupuncture emphasizes need for thorough medical evaluation before such procedures. R I Med J 1982;65:251-3.

11. Woo PC, Lau SK, Wong SS, Yuen KY. Staphylococcus aureus subcutaneous abscess complicating acupuncture: need for implementation of proper infection control guidelines. New Microbiol 2003;26:169-74.

12. Majeski JA, Alexander JW. Early diagnosis, nutritional support, and immediate extensive debridement improve survival in necrotizing fasciitis. Am J Surg 1983;145:784-7.

13. Wall DB, de Virgilio C, Black S, Klein SR. Objective criteria may assist in distinguishing necrotizing fasciitis from nonnecrotizing soft tissue infection. Am J Surg 2000;179:17-21.

14. Majeski J, Majeski E. Necrotizing fasciitis: improved survival with early recognition by tissue biopsy and aggressive surgical treatment. South Med J 1997;90:1065-8. 